\title{
Influence of phytochemicals in piper betle linn leaf extract on wound healing
}

\author{
Le Thi Lien ${ }^{1+}$, Nguyen Thi Tho ${ }^{1+}$, Do Minh Ha ${ }^{1,2}$, Pham Luong Hang ${ }^{1,2}$, Phan Tuan Nghia ${ }^{1,2}$ \\ and Nguyen Dinh Thang ${ }^{1,2^{*}}$
}

\begin{abstract}
Background: Wound healing has being extensively investigated over the world. Healing impairment is caused by many reasons including increasing of free-radicals-mediated damage, delaying in granulation tissue formation, reducing in angiogenesis and decreasing in collagen reorganization. These facts consequently lead to chronic wound healing. Piper betle Linn (Betle) leaves have been folklore used as an ingredient of drugs for cutaneous wound treatment. However, the effect of betle leaf on wound healing is not yet well elucidated. In this study, we aimed to investigate the healing efficacy of methanol leaf extract of Piper betle Linn on proliferation of fibroblast $\mathrm{NIH3T3}$ cells as well as full-thickness burn and excision wounds in swiss mice.
\end{abstract}

Methods: Scratch wound healing assays were conducted to examine the effects of betle leaf extract on healing activity of fibroblast cells. Burn and excision wounds on swiss mouse skins were created for investigating the wound healing progress caused by the betle leaf extract. Malondialdehyde (MDA) was also evaluated to examine the products of lipid hydroperoxide (LPO) under conditions of with or without betle leaf extract treatment.

Results: The results of this study showed that Piper betle Linn leaf extract in methanol increased proliferation of $\mathrm{NIH} 3 \mathrm{~T} 3$ cells and promoted wound healing in vitro and in vivo with both burn wound and excision wound models. In addition, this extract significant decreased level of malondialdehyde (MDA) in liver of treated-mice compared with that in non-treated mice.

Conclusions: Our results suggest that Piper betle Linn can be used as an ingredient in developing natural origin drugs for treatment of cutaneous wounds.

Keywords: Piper betle Linn, Leaf extract, Wound healing, Malondialdehyde (MDA), Fibroblast (NIH3T3)

\section{Background}

The skin is one of the largest organs and plays important biological roles in the body. Skin contributes in maintaining the fluid homeostasis, regulating the thermo effects, sending sensory signals to the brain, and metabolizing various substances $[1,2]$. The skin is also the first barrier to protect the body against the infections from the environment. Any damage of this physical barrier may lead to attacks of pathogens and consequently cause infection in the body $[1,2]$. Healing impairment is caused by many reasons

\footnotetext{
* Correspondence: ndthang@hus.edu.vn

${ }^{\dagger}$ Equal contributors

'Department of Biochemistry and Plant Physiology, VNU University of Science, Vietnam National University, 334 Nguyen Trai St., Thanh Xuan District, Hanoi, Vietnam

${ }^{2}$ Key laboratory of Enzyme and Protein Technology (KLEPT), VNU University of Science, Vietnam National University, Hanoi, Vietnam
}

including increasing in free-radicals-mediated damage, delaying in granulation tissue formation, reducing in angiogenesis and decreasing in collagen reorganization. These facts consequently led to chronic wound healing $[3,4]$.

Several plants and their products are used in folk medicine to treat wounds [4-8]. Piper betle Linn is a member of Piperaceae family and to be cultivated in most of South and Southeast Asia including Vietnam. It could be used as an ingredient in drugs because of its medicinal properties. Betle leaves contain main chemical components such as betal-phenol, chavicol and other phenolic compounds. These components might give strong potentials in antifungi, anti-bacteria properties of betle [9]. Betle leaf also has been reported that it exhibit potentials in wound healing treatment and other diseases [10-16]. However, the effect of betle leaf on wound healing is not yet well examined. 
Topical anti-bacterial agents and disinfectants are good in protecting against infection; however these agents may cause the allergic reactions and skin irritations and result in the rate of skin regeneration and increases the recovery time $[17,18]$. Although there are modern methods such as recombinant growth factors and tissue-engineered wound dressings used for wound treatments, they are so expensive for patients in the low-income countries. Therefore, in developing countries, many drugs originated from medicinal plants are being used as alternative and complementary systems of medicines to treat wounds and several wound healing processing diseases [4-8].

Hence, the present study was undertaken to examine the influence of methanol betle leaf extract on proliferation of fibroblast NIH3T3 cells and healing of burn and excision wounds in swiss mice.

\section{Methods}

\section{Plant material}

Piper betle Linn (Betle) leaves were collected from Vietnam Pharmacy Institute in September 2013 and identified at the Department of Biochemistry and Plant physiology, Faculty of Biology, VNU University of Science, Vietnam National University, Hanoi, Vietnam.

\section{Preparation of leaf extract}

Fresh leaves of betle were cleaned and washed thoroughly with water and re-washed with distilled water. Washed fresh leaves were shade dried, powdered mechanically, and sieved by using a mesh. In the preparation of organic solvent extracts, $5 \mathrm{~g}$ of powdered material was refluxed with $1 / 10 \mathrm{w} / \mathrm{v}$ in a soxhlet apparatus for an hour. The extract was filtered, and the solvent was removed under reduced pressure at $40 \pm 5{ }^{\circ} \mathrm{C}$ using a rotary flash evaporator. The scheme of the extraction procedure was presented in the Fig. 1 and the effectiveness of extraction procedure was presented in the Table 1 . We used simultaneously three types of organic solvents including nhexane, EtOAc and $\mathrm{MeOH}$ with gradually increasing in polarities to extract substances in the leaves of betle. Normally, substances which could be dissolved in methanol (alcohol) have high biological and pharmaceutical activities. Therefore, in this study we focused on investigate the effect of methanol extract on wound healing.

\section{Drug formulations}

Drug formulation was prepared from methanol extract. For topical administration, $5 \mathrm{~g}$ of the methanol extracts was separately incorporated with $100 \mathrm{~g}$ of $2 \%$ sodium alginate to get $5 \% \mathrm{w} / \mathrm{w}$ gel. The drug formulation was prepared every fourth day. The drug was daily administered on mice.

\section{Cell culture}

Fibroblasts (NIH3T3) (Riken Bioresource Center, Japan) was cultured in DMEM with 10 \% FBS supplemented with $10 \%$ Fetal Bovine Serum (FBS) and $1 \%$ Penicillin/ Streptomycin at $37{ }^{\circ} \mathrm{C}$ in $5 \% \mathrm{CO}_{2}$ on collagen-coated dishes [19].

\section{Crystal violet assay}

Crystal violet assay was performed using the method previously described in our reports $[20,21]$. Briefly, cells $\left(3 \times 10^{4}\right.$ cells $)$ were plated in six-well plates and cultured for $24 \mathrm{~h}$. Cells were then treated with or without methanol extract of betle and cultured for further 3 days. The viable adherent cells were fixed with $10 \%$ formalin and stained with $0.1 \%$ crystal violet. Absorbance at $595 \mathrm{~nm}$ in the stained cells solubilized with $0.1 \%$ SDS was measured using a microplate reader.

\section{Scratch wounding assay}

Cell wound healing was performed as described previously studies [20, 22]. Six-well plates were incubated overnight in $1 \mathrm{~mL}$ of RPMI 1640 media containing collagen at $40 \mu \mathrm{g} / \mathrm{ml}$. Cells were cultured in RPMI 1640 (10 \% FBS) in the collagen-coated plate until the cell confluence reached to more than $90 \%$. Scratch wounds were created in confluent monolayers using a sterile p200 pipette tip. After that, cell plate was washed three times with PBS to remove the suspended cells. Then, the wounded monolayers were cultured in RPMI 1640 medium. After incubation for $24 \mathrm{~h}$, repopulations of the wounded areas were observed under microscope (OLYMPUS). The migration distances of cells into the scratching areas were measured and calculated.

\section{Animals}

Swiss mice weighing 15-20 g were purchased from Vietnam National Institute of Hygiene and Epidemiology, Hanoi and maintained at standard housing conditions. The animals were fed with a commercial diet [23] (also from the Vietnam National Institute of Hygiene and Epidemiology) and water. The Vietnam National University Ethical Committee permitted the study.

\section{Evaluation of wound healing activity}

For the assessment of the wound-healing activity, burn and excision wound models were used [24, 25]. Three groups, each containing five animals, including control group (group I), burn wound group (group II) and excision wound group (group III) were used. Fifty milligrams (50 mg) of the formulated drug was topically applied for each animal once a day. The Group I animals were treated by topical applications of $5 \% \mathrm{w} / \mathrm{w}$ gel, while the Groups II and III animals were treated with ethanol extracts. The animals were anesthetized as described by Morton and 


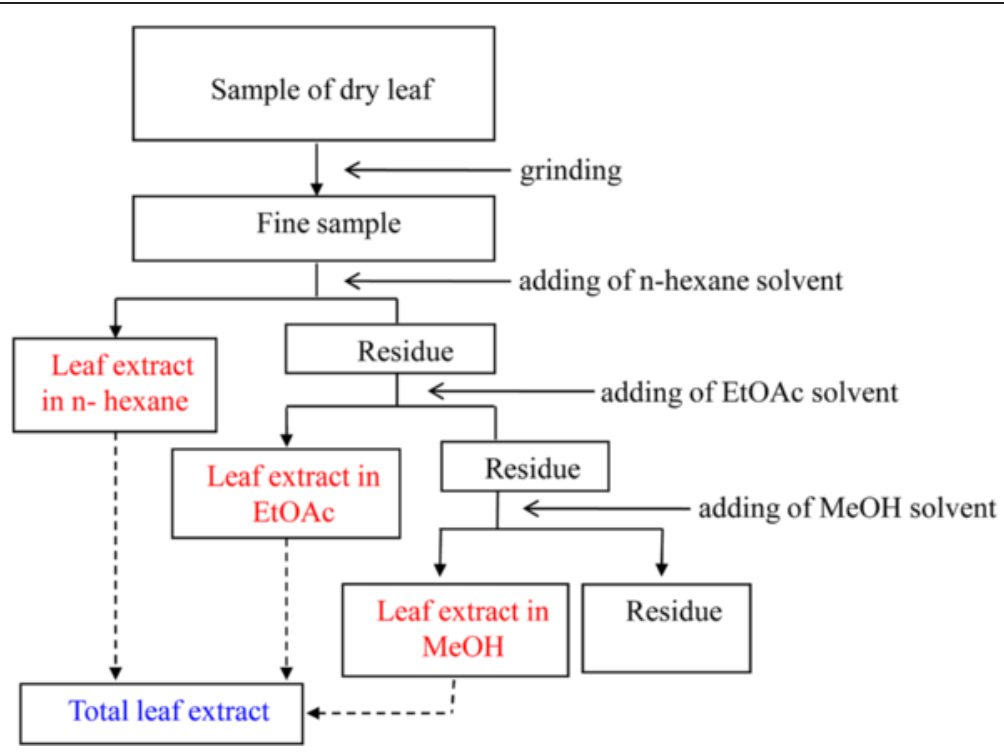

Fig. 1 The scheme of leaf extraction procedure with three types of organic solvents including n-hexane, EtOAc and Methanol

Malone [24] using diethylether $\left(\mathrm{C}_{2} \mathrm{H}_{5} \mathrm{OC}_{2} \mathrm{H}_{5}\right)$. For the excision wound model, the skin of the impressed area of mouse was excised to full thickness to obtain a wound area of about $120 \mathrm{~mm}^{2}$ [24]. For burn wound model, fullthickness burn wound was created by using an aluminum metal rod (diameter $120 \mathrm{~mm} \times 100 \mathrm{~mm}$ ) heated to $90{ }^{\circ} \mathrm{C}$. Hot rod was exposed on the shaved area in the skin of mouse for $20 \mathrm{~s}$. The drug was topically applied once a day till complete epithelialization, starting from the day of the operation. Then, wound areas and wound epithelizations were measured at regular intervals of time to see the percentage of wound closure and formation of new epithelial tissues. The percentages of wound closure were recorded on days 2, 4, 6 and 3, 7, 15 for burn wounds and excision wounds, respectively.

\section{MDA analysis}

After wounds were totally healed, mice were anesthetized by intraperitoneal injection of ketamine and sacrificed. Liver and soft leg tissues were collected and stored as frozen tissues in liquid nitrogen for biochemically MDA analysis. Tissue samples (300 mg for each) were homogenized in ice-cold tamponade containing $150 \mathrm{mM} \mathrm{KCl}$ for determination of MDA. MDA levels were assayed for products of lipid hydroperoxide (LPO). MDA was measured with thiobarbituric acid at $532 \mathrm{~nm}$ using a spectrofluorometer, as described previously [26, 27].

\section{Statistical analysis}

In this study, all experiments were repeated three times and collected data were statistical analysis with suitable methods. To compare two groups, Mann-Whitney $U$-test was used in case of non-parametric and Student's $t$-test was used for parametric. To compare multi groups with control group, one-way ANOVA analysis and Dunnett post-hoc test were used. To assess the combination effect of two factors, two-way ANOVA with replication analysis and Tukey's HSD post-hoc test were used. The significant differences were set at three levels with $P<0.05$ [20].

\section{Results}

Betle promoted proliferation of fibroblast NIH3T3 cells

NIH3T3 cells were treated with betle at various concentrations $(0,0.25,0.5,1.0,2.5,5.0,10$ and $20 \mu \mathrm{g} / \mathrm{mL})$. The results were presented in photos (Fig. 2a) and a graph (Fig. 2b). At the low concentrations of 0.5 and $1.0 \mu \mathrm{g} /$ $\mathrm{mL}$, betle had no effect on proliferation of NHI3T3. However, at high concentrations of 10 and $20 \mu \mathrm{g} / \mathrm{mL}$, betle was so high toxic to NHI3T3 cells with more than $90 \%$ and $99 \%$ cells dead, respectively. Interestingly, at

Table 1 Consecutive extraction efficiency of phytochemicals from Polygonum multiflorum in three different solvents including n-Hexane, EtOAc and $\mathrm{MeOH}$

\begin{tabular}{|c|c|c|c|c|c|}
\hline \multirow[t]{2}{*}{ Name } & \multirow{2}{*}{$\begin{array}{l}\text { Total wet } \\
\text { weight (gram) }\end{array}$} & \multirow{2}{*}{$\begin{array}{l}\text { Total dry } \\
\text { weight (gram) }\end{array}$} & \multicolumn{3}{|c|}{ Dry extract weight (gram)/10g dry weight } \\
\hline & & & n-Hexane & EtOAc & $\mathrm{MeOH}$ \\
\hline Piper betle $\mathrm{L}$. & 400 & 77.6 & 1.07 & 2.89 & 1.40 \\
\hline
\end{tabular}




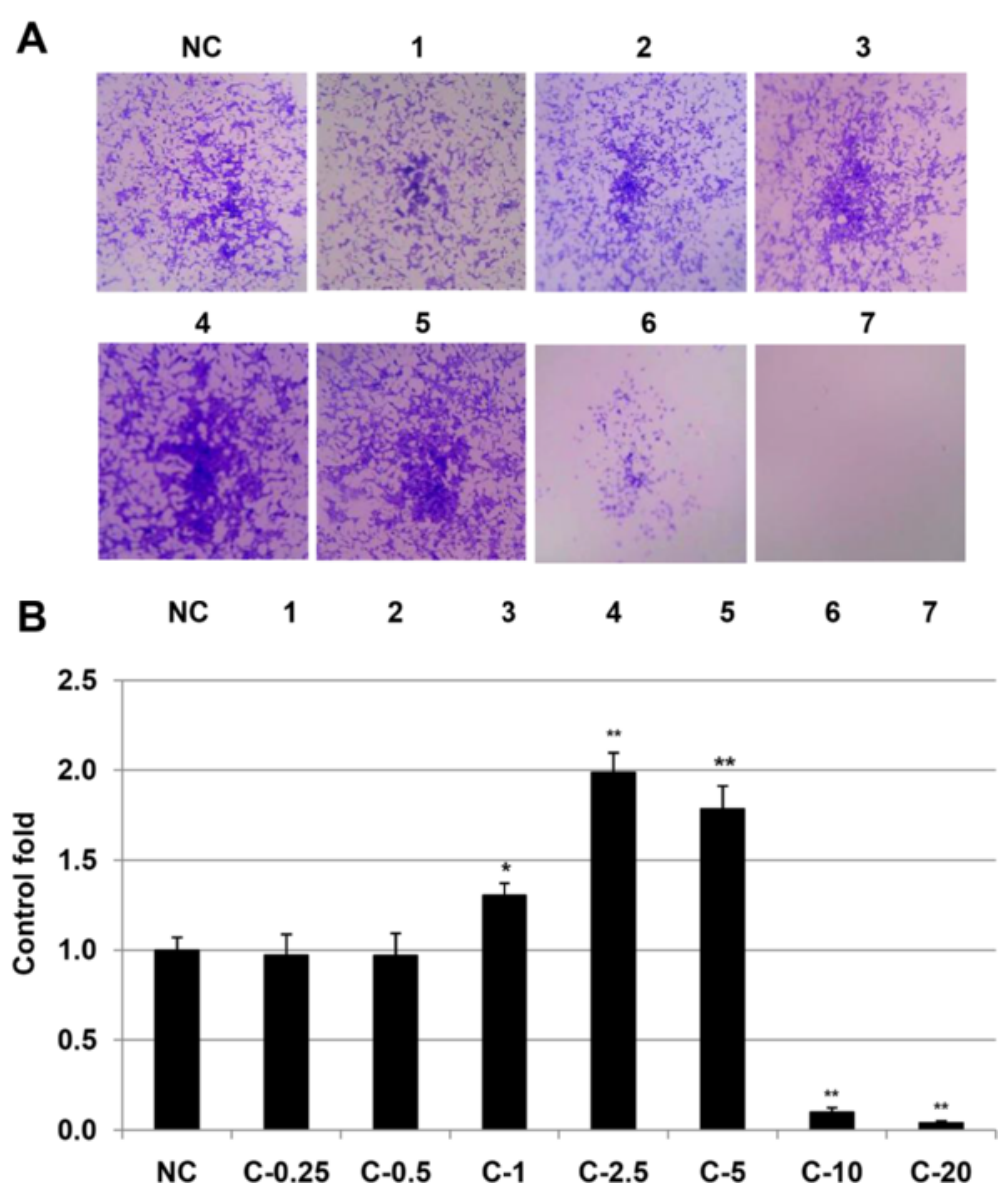

Fig. 2 Effect of methanol leaf extract at various concentrations on proliferation of NIH3T3 cells were presented in photos (a) and a graph (b). Leaf extract concentration tested including: $0.25 \mu \mathrm{g} / \mathrm{mL}$ (lane 1), $0.5 \mu \mathrm{g} / \mathrm{mL}$ (lane 2), $1.0 \mu \mathrm{g} / \mathrm{mL}$ (lane 3), $2.5 \mu \mathrm{g} / \mathrm{mL}$ (lane 4), $5.0 \mu \mathrm{gg} / \mathrm{mL}$ (lane 5), $10.0 \mu \mathrm{gg} / \mathrm{mL}$ (lane 6), $20.0 \mu \mathrm{g} / \mathrm{mL}$ (lane7). ${ }^{*}$ and ${ }^{*}$ Significantly different $(p<0.05$, and 0.01 , respectively) from the control by the one-way ANOVA analysis and Dunett post-hoc test

concentrations 1.0, 2.5 and $5.0 \mu \mathrm{g} / \mathrm{mL}$, betle significantly increased proliferation of NIH3T3 cells up to 1.31, 2.0 and 1.78 folds compared with non-treated cells, respectively. Fibroblast NIH3T3 cells play important role in collagen synthesis and collagen formation in skin tissue during wound healing process [28], therefore our results suggested that betle at suitable concentrations was able to increase of NIH3T3 cell proliferation and consequently it may promote the rate of wound healing.

\section{Betle increased healing rate of scratch wound in vitro}

We next investigated the healing rate of NIH3T3 by scratch wound healing assay. NHI3T3 were cultured in starving medium (0.5\% FBS) for $8 \mathrm{~h}$ before treated or/ and untreated with betle at concentration of $5 \mu \mathrm{g} / \mathrm{mL}$ for 2 days untill the cell population reached up to more than $90 \%$ confluence. Then, scratch wound healings were examined within $24 \mathrm{~h}$. Healing activities of NIH3T3 cells were presented in the Fig. 3. Our result showed that healing velocity of NIH3T3 with betle treatment was 1.53 fold higher than that of untreated cells. The migration of cells into the wounds plays key role in wound healing process.

Betle increased healing rate of burn wounds in swiss mice Burn wounds $\left(120 \mathrm{~mm}^{2}\right)$ were created by the hot metal rod on the back skins of the mice and topical treated with drug daily for 7 days. The wound areas were observed and measured for every two days. The results were presented in photos (Fig. 4a) and a graph (Fig. 4b). It showed that $5 \%$ betle drug gel had good effect in healing rate of the burn wounds. The average percentages of burn healing areas were 32, 68 and 80 in betletreated mice and 20, 38 and 43 in control mice at the $2^{\text {nd }}, 4^{\text {th }}$ and the $6^{\text {th }}$ days post-wounding, respectively.

\section{Betle increased healing rate of excision wounds in swiss} mice

The impressed areas of the back skins of swiss mice were excised to full thickness to obtain wound areas of 


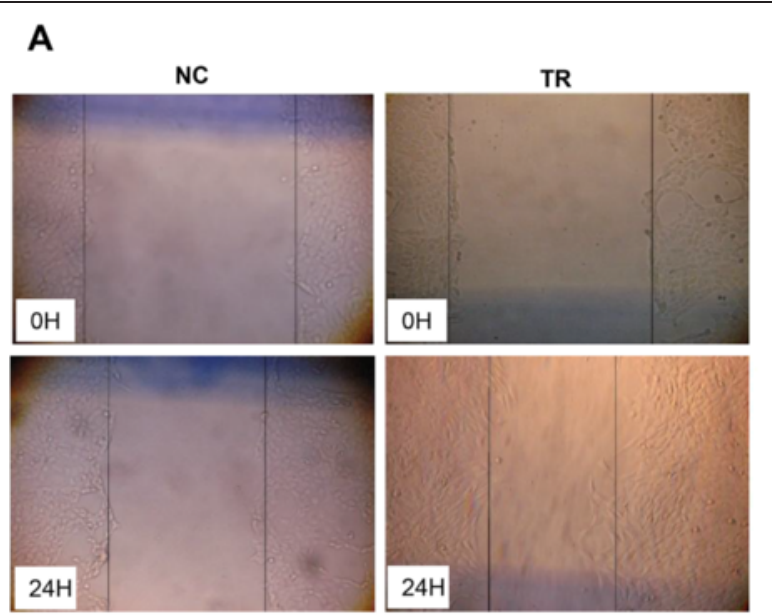

B

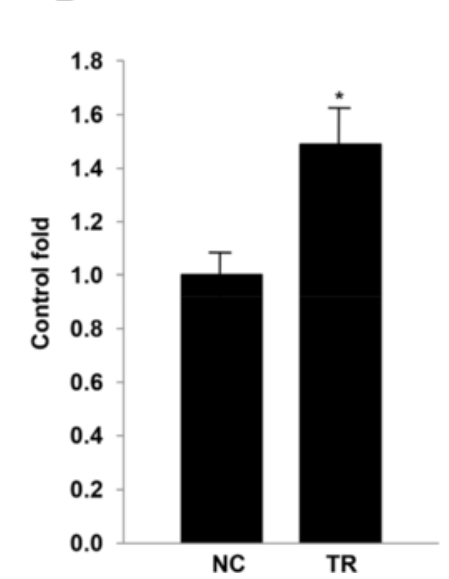

Fig. 3 Effect of methanol leaf extract on scratch wound healing of NIH3T3 cells were presented in photos (a) and a graph (b). Leaf extract concentration tested including: $0.0 \mu \mathrm{g} / \mathrm{mL}$, and $5.0 \mu \mathrm{g} / \mathrm{mL}$. ${ }^{*}$ and ${ }^{*}$ Significantly different $(p<0.05$, and 0.01 , respectively) from the control by the Mann-Whitney U-test

$120 \mathrm{~mm}^{2}$. Wounds were daily topical administrated with drug for 15 days and the areas of wounds were measured at the third, the seventh and the fifteenth days post-wounding. The results were presented in photos and in a graph in the Fig. 5. Our results indicated that the $5 \%$ betle drug gel had positive effect on excision wound healing in swiss mice. At the third day postwounding, there were no difference in the rates of wound healing between betle-treated mice and control mice, however at the seventh day and fifteenth day there

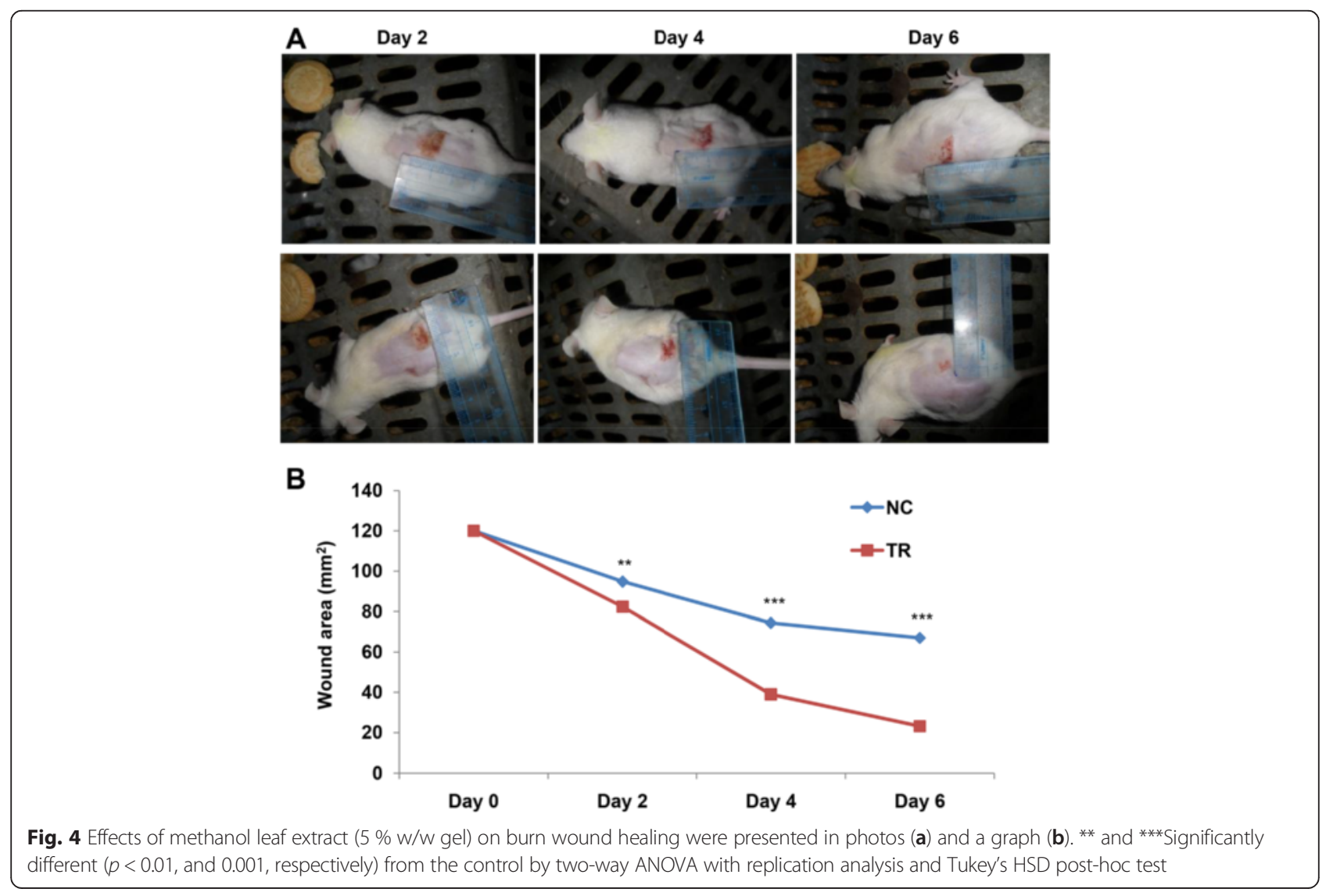




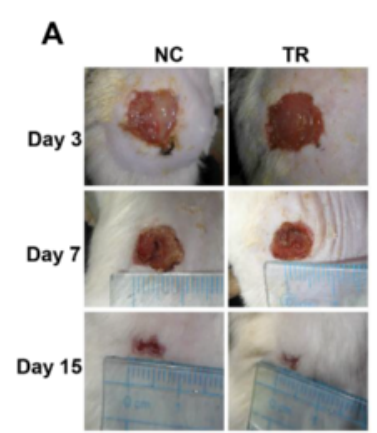

B

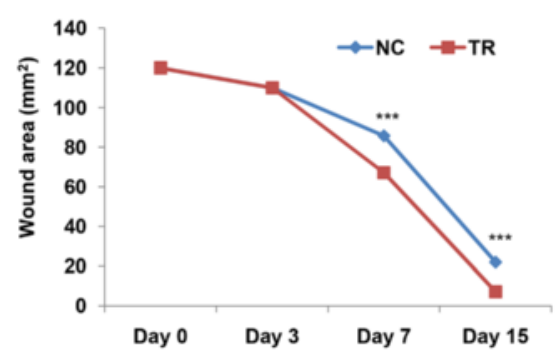

C

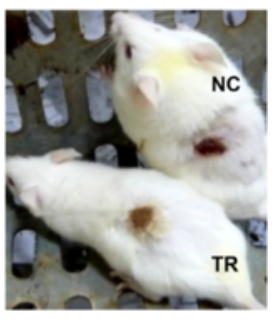

Fig. 5 Effects of methanol leaf extract ( $5 \%$ w/w gel) on excision wound healing were presented in photos (a, c) and a graph (b). ${ }^{* * *}$, Significantly different $(p<0.001)$ from the control by two-way ANOVA with replication analysis and Tukey's HSD post-hoc test

were significant differences in the rates of wound healing between betle-treated mice (TR) and control mice (NC). The average percentages of wound healing areas at the seventh day and fifteenth day were 44 and 94 for betletreated mice and 28 and 82 for control mice, respectively. Wound healing is related to two processes including wound contraction and wound re-epitheliazation [3]. However, because of loose skin of rodents, wound closure might be caused mainly by wound contraction. Therefore it was quite hard to clarify the effect of drug on the wound re-epitheliazation. Thus, we decided to create wounds with large areas $\left(225 \mathrm{~mm}^{2}\right)$ for sure that it will take a long time for skin contraction in order that we can observe wound healing by re-epithelialization. Our results showed that at the 12th day post wounding, reepitheliazation of the wounds on the skin of the Piper betle-treated mice were better than that of the control mice. While the control wounds were still in concave forms with red colors, the Piper betle-treated wounds were filled with formation of dry scales (Fig. 5c). This result suggested that drug gel was not only able to increase skin contraction but also to promote reepitheliazation of the wounds.

\section{Betle decreased activity of MDA}

In generally, natural leaf extracts contain many polyphenolic compounds acting as antioxidant agents [29]. Lipid hydroperoxides (LPO) are products from oxidative damage in lipid-containing structures in cells [30]. Malondialdehyde (MDA) is considered as an important marker for LPO [26]. The high level of MDA produced in the tissues indicates that the tissues might be injured and DNA might be damaged. In the other hand, the excessive MDA could bind to free amino groups of proteins and result in the formation of MDA-modified protein adducts [26]. Therefore we decided to examine the effect of betle leaf extract on the levels of MDA in liver and leg soft tissues of mice. Our results showed that levels of MDA in liver and leg soft tissues of betletreated mice were $18 \%$ and $7 \%$ lower than that of nontreated mice, respectively (Fig. 6).

\section{Discussion}

In this study, we consecutively used three organic solvents with gradually increase in polarity including nhexane, ethylacetate and methanol to extract phytochemicals in the betle. In generally, the two first solvents
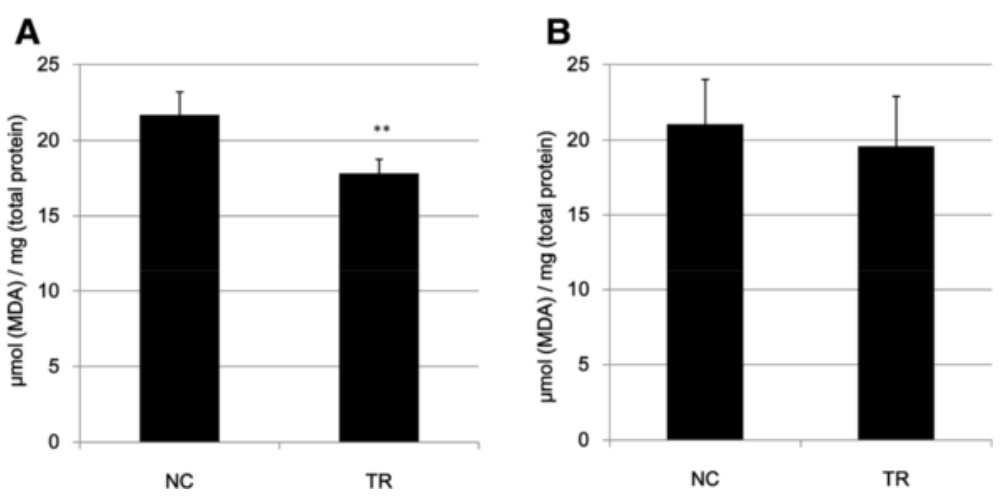

Fig. 6 Effects of leaf extract ( $5 \%$ w/w gel) on concentrations of malondialdehyde (MDA) in liver tissues (a) and leg soft tissues (b) of non-treated $(\mathrm{NC})$ and betle-treated mices were examined by MDA analysis. ${ }^{*}$, Significantly different $(p<0.01)$ from the control by Student's $t$-test 
Table 2 Two-way Anova with replication analysis and Tukey's HSD post-hoc test showed combination effects of leaf extract and treatment time on burn wound healing

\begin{tabular}{lllll}
\hline & Day 0 & Day 2 & Line segment slopes & Absolute difference between slopes \\
NC & 120 & 94.8 & -25.2 & 12.4 \\
TR & 120 & 82.4 & -37.6 & Absolute difference between slopes \\
& Day 2 & Day 4 & Line segment slopes & 23.0 \\
NC & 94.8 & 74.4 & -20.4 & Absolute difference between slopes \\
TR & 82.4 & 39 & -43.4 & 8.4 \\
& Day 4 & Day 6 & Line segment slopes & \\
NC & 74.4 & 67 & -7.4 & -15.8 \\
\hline
\end{tabular}

of n-hexane and ethylacetate are used to eliminate of substances which have non- or low- biological activities from the samples before extracting in methanol to collect substances which have biological activities. And then, we had tried to investigate the effects of not only methanol extract but also n-hexane and ethylacetate extracts on NIH3T3 cells, however, it was not showed the impressive effects of n-hexane and ethylacetate extracts on the cells (data not shown).

However, our in vitro results of this study showed that at the concentrations of $2.5-5 \mu \mathrm{g} / \mathrm{mL}$ betle leaf extract in methanol had positive effects on proliferation of NIH3T3 cells. Basing on this, we chose the concentration of $5 \%$ $(\mathrm{v} / \mathrm{v})$ of drug gel for in vivo experiments but not perform a real dose-dependent curve to obtain EC50 and EC05. Because our methanol extract used in this study was still in crude form (i.e., there may have many substances in the extract). It was not so important to determine the very precise concentration of the crude extract; however this kind of experiment should be done in case of using single substance. Therefore, we followed the previous reports $[1,2,5,6]$ to select the concentration of extract for in vivo experiments as about 10 times higher than that used for in vitro experiments $(5 \% \mathrm{~V} / \mathrm{V})$.

Our in vivo experiments revealed that betle leaf extract gel significantly increased healing rates of burn wounds and excision wounds in swiss mice. Moreover, statistical results by two-way Anova with replication analysis and Tukey's HSD post-hoc test showed that burn wound healing were affected by both leaf extract and treatment time and there were interaction between these two factors in both cases of burn wound (Fig. 4) and excision wound (Fig. 5). In the case of burn wound, it was also indicated that betle leaf extract had the strongest effect on wound healing in the period of 2-4 days post wound making (PWM), followed by periods of 0-2 days PWM the smallest effect in the period of 4-6 days PWM with significant differences (Table 2). In the case of excision wound, in the period of 0 3 days PWM, there was no difference in wound healing rate between control groups and treated groups; however, at the period of 3-7 days PWM, the effect of betle leaf extract was strongest and followed by period of 7-15 days PWM with significant differences (Table 3). These statistic results may suggest a hint that we can screen various leaf extracts on wound healing activities and determine the wound healing effects of these extracts at different periods during treatment times to develop an optimum clinical protocol by changing or combining of these various leaf extracts.

\section{Conclusions}

In this preliminary research, we also found that betle can induce proliferation of fibroblast cells and promote

Table 3 Two-way Anova with replication analysis and Tukey's HSD post-hoc test showed combination effects of extract and treatment time on excision wound healing

\begin{tabular}{lllll}
\hline & Day 0 & Day 3 & Line segment slope & Absolute difference between slopes \\
NC & 120 & 110 & -10 & 0 \\
TR & 120 & 110 & -10 & Absolute difference between slopes \\
& Day 3 & Day 7 & Line segment slope & 18.6 \\
NC & 110 & 85.8 & -34.2 & Absolute difference between slopes \\
TR & 110 & 67.2 & -52.8 & 3.8 \\
NC & Day 7 & Day 15 & Line segment slopes & -63.8 \\
TR & 85.8 & 22 & -60 & \\
\hline
\end{tabular}


wound healing in swiss mice but not caused to any strange behavior or phenomenon of treated mice. Moreover, it was revealed the fact that betle promoted wound healing progression with lowering levels of MDA in liver and leg soft tissues of treated mice.

Taken together, our results suggest that Piper betle can be used in alternative and complementary systems to improve efficacy of medicines used for cutaneous wound treatment.

\section{Competing interests}

The authors declare that there is no conflict of interests regarding the publication of this paper.

\section{Authors' contributions}

NDT: conception and experimental design, writing of the manuscript, manuscript revision and funding body. LTL, NTT and DMH: experimental performing, collection and analysis of data. PTN: interpretation of data and preparation of the manuscript. PLH: Help to revise the manuscript. All authors read and approved the final manuscript.

\section{Acknowledgements}

This work was supported by Grants-in-Aid for Scientific Research under grant number KLEPT-14-02.

\section{Financial disclosure}

The funders had no role in study design, data collection and analysis, decision to publish, or preparation of the manuscript.

Received: 5 July 2015 Accepted: 26 November 2015

Published online: 01 December 2015

\section{References}

1. Upadhyay NK, Kumar R, Siddiqui MS, Gupta A. Mechanism of woundhealing activity of hippophae rhamnoides L. leaf extract in experimental burns. Evid Based Complement Alternat Med. 2011;2011:Article ID 659705. 10.1093/ecam/nep189.

2. Gupta A, Upadhyay NK, Sawhney RC, Kumar R. A poly-herbal formulation accelerates normal and impaired diabetic wound healing. Wound Repair Regen. 2008;16:784-90.

3. Zielins ER, Atashroo DA, Maan ZN, Duscher D, Walmsley GG, Hu M, et al. Wound healing: an update. Regen Med. 2014;9(6):817-30. doi:10.2217/rme.14.54.

4. Rowan MP, Cancio LC, Elster EA, Burmeister DM, Rose LF, Natesan S, et al. Burn wound healing and treatment: review and advancements. Crit Care. 2015;19:243. doi:10.1186/s13054-015-0961-2.

5. Shetty S, Udupa S, Udupa L. Evaluation of antioxidant and wound healing effects of alcoholic and aqueous extract of Ocimum sanctum Linn in rats. Evid Based Complement Alternat Med. 2008;5:95-101.

6. Nayak BS, Sandiford S, Maxwell A. Evaluation of the wound-healing activity of ethanolic extract of Morinda citrifolia L. leaf. Evid Based Complement Alternat Med. 2009;6:351-6.

7. Phan TT, Hughes MA, Cherry GW. Enhanced proliferation of fibroblasts and endothelial cells treated with an extract of the leaves of Chromolaena odorata (Eupolin), an herbal remedy for treating wounds. Plast Reconstr Surg. 1998;101:756-65.

8. Gupta A, Kumar R, Pal K, Banerjee PK, Sawhney RC. A preclinical study of the effects of seabuckthorn (Hippophae rhamnoides L.) leaf extract on cutaneous wound healing in albino rats. Int J Low Extrem Wounds. 2005;4:88-92.

9. Maisuthisakul P, Pongsawatmanit R, Gordon MH. 2007. Assessment of phenolic content and free-radical scavenging capacity of some Thai indigenous plants. Food Chem. 2007;100:1409-18.

10. Sudrik S, Fegade S, Shinde M. Anthelmintic activity of Piper bBetle Linn, (paan/ngagavalli) aqueous extract. Res J Pharm Biol Chem Sci. 2012:3:467-70.

11. Chu NS. Effects of betel chewing on the Central and autonomic nervous systems. J Biomed Sci. 2001:8:229-36.

12. Rahman SA. Anti-ulcer effects of Piper betel, Solanum nigrum and Zingibercassumunar on ulceration induced by selected ulcerogens in rats. Master's thesis, University Putra Malaysia. 2009;pp. 4.
13. Nalina T, Rahim ZHA. The crude aqueous extract of piper betle $L$. and its antibacterial effect towards streptococcus mutans. Am J Biotech Biochem. 2007;3:10-5

14. Sarkar A, Sen R, Saha P, Ganguly S, Mandal G, Chatterjee M. An ethanolic extract of leaves of Piper betle (Paan) Linn mediates its antileishmanial activity via apoptosis. Parasitol Res. 2008:102:1249-55.

15. Singh M, Shakya S, Soni VK, Dangi A, Kumar N, Bhattacharya SM. The $\mathrm{n}$-hexane and chloroform fractions of Piper betle L. trigger different arms of immune responses in BALB/C mice and exhibit antifilarial activity against human lymphatic filarid Brugia malayi. Int Immunopharmacol. 2009;9:716-28.

16. Sarkar M, Gangopadhyay P, Basak B. The reversible antifertility activity of Piper betel Linn. on Swiss albino male mice. Contraception. 2000;62:271-4.

17. Thomas GW, Rael LT, Bar-Or R, Shimonkevitz R, Mains CW, Slone DS, et al. Mechanisms of delayed wound healing by commonly used antiseptics. J Trauma. 2009;66:82-90.

18. Lee ARC, Leem H, Lee J, Park KC. Reversal of silver sulfadiazine-impaired wound healing by epidermal growth factor. Biomaterials. 2005;26:4670-6.

19. Thang ND, Yajima I, Ohnuma S, Ohgami N, Kumasaka YM, Ichihara G, et al. Enhanced constitutive invasion activity in human nontumorigenic keratinocytes exposed to a low level of barium for a long time. Environ Toxicol. 2015;30:161-7.

20. Yajima I, Uemura N, Nizam S, Khalequzzaman M, Thang ND, et al. Barium inhibits arsenic-mediated apoptotic cell death in human squamous cell carcinoma cells. Arch Toxicol. 2012:86:961-73.

21. Thang ND, Yajima I, Kumasaka YM, Kato M. Bidirectional functions of arsenic as a carcinogen and an anti -cancer agent in human squamous cell carcinoma. PLoS One. 2014;9(5):e96945.

22. Jiang XP, Zhang DX, Teng $M$, Zhang $Q$, Zhang JP, Huang YS. Downregulation of CD9 in keratinocyte contributes to cell migration via upregulation of matrix metalloproteinase-9. PLoS One. 2013;8(10):e77806.

23. Huang H, Pierstorff E, Osawa E, Ho D. Active nanodiamond hydrogels for chemotherapeutic delivery. Nano Lett. 2007;7:3305-14.

24. Mortan JJP, Malone MH. Evaluation of vulnery activity of open wound procedure in rats. Arch Int Pharmacodyn Ther. 1972;196:117-26.

25. Gupta A, Upadhyay NK, Parthasarathy S, Rajagopal C, Roy PK. Nitrofurazoneloaded PVA-PEG semi-IPN for application as hydrogel dressing for normal and burn wounds. J Appl Polym Sci. 2013;28:4031-9.

26. Schubert SY, Neeman I, Resnick N. A novel mechanism for the inhibition of NF-kappaB activation in vascular endothelial cells by natural antioxidants. FASEB J. 2002;16:1931-3.

27. Ilbey YO, Ozbek E, Simsek A, Cekmen M, Somay A, Tasci Al. Effects of pomegranate juice on hyperoxaluria-induced oxidative stress in the rat kidneys. Ren Fail. 2009;31:522-31.

28. Zhou S, Salisbury J, Preedy VR, Emery PW. Increased collagen synthesis rate during wound healing in muscle. PLOS One. 2003;8:e58324.

29. de Nigris F, Williams-Ignarro S, Lerman LO, Crimi E, Botti C, Mansueto G, et al. Beneficial effects of pomegranate juice on oxidation-sensitive genes and endothelial nitric oxide synthase activity at sites of perturbed shear stress. Proc Natl Acad Sci U S A. 2005;102:4896-901.

30. Girotti AW. Lipid hydroperoxide generation, turnover, and effector action in biological systems. J Lipid Res. 1998;39:1529-42.
Submit your next manuscript to BioMed Central and we will help you at every step:

- We accept pre-submission inquiries

- Our selector tool helps you to find the most relevant journal

- We provide round the clock customer support

- Convenient online submission

- Thorough peer review

- Inclusion in PubMed and all major indexing services

- Maximum visibility for your research

Submit your manuscript at www.biomedcentral.com/submit 